\title{
TEACHER STRATEGIES OF TEACHING READING IN EFL CLASS
}

\author{
Oleh:
}

Ilham

Dosen Pendidikan Bahasa Inggris FKIP UM Mataram

\begin{abstract}
This study aims to investigate the teacher strategies in teaching reading comprehension. This study employed qualitative method because it is conducted in the natural setting. In this study, observation was conducted directly in the particular setting in which he interested to observe and collect the data (Fraenkel and Wallen, 1993: 380). The researcher used classroom observation to find out teachers' strategies in teaching reading. In this study, a non-participant classroom observation was conducted by the researcher. The analysis process was commenced by making verbatim transcription of classroom interactions. Then, the transcriptions were read repeatedly. During the reading process, the researcher employed coding activity by matching the data with the research questions. This study found that the strategies provided by teacher are in the pre-reading stage, in the while-reading stage, and in the post-reading stage.
\end{abstract}

Keywords: strategies, EFL class, coding.

\section{BACKGROUND OF THE STUDY}

Teacher strategy in teaching reading comprehension is very important to analyze by the teacher to solve the complex problem when the teacher teach reading at the classroom activities. Many teachers have developed the teaching strategies and approaches aiming to help students to learn reading skill effectively.

The significance of reading strategy is indicated implicitly in the Indonesia National Curriculum of 2006. In this curriculum, it is stated that the objective of teaching reading, as one of the four major skills, in learning English as foreign language in the Junior High School is to develop the students' ability to read and to get the message comprehensively from particular reading texts (BSNP, 2006). Relating to the essence of this curriculum, Nuttal (1996: 4) states that one of very important reading purposes is to get meaning from a text. This means about the process how the reader decodes the message from the text. In a similar vein, Nunan (1999: 249) exposed that an enormous amount of time, money and effort is spent for teaching reading in elementary and secondary school around the world.

In getting the meaning from the text, the reader needs a comprehension strategy. It is supported by (Hillerich: 1983: 125) that states the major goal for any reading activities is comprehension. It means that it has to do with strategy to understand a written text. Many strategies for teaching reading comprehension have developed by experts such as Hillerich (1983), Tierney (1990), and Anderson (1999).
In line with this study, Li and Wilhelm (2008) explored to compare the reading strategy instruction use by two teachers in teaching reading in senior middle school classrooms on China's mainland. This study revealed that the less-experience teacher was more aware of integrating theory into actual practice while taking a more learner-centered approach. Meanwhile the more-experienced teacher was more concerned with testing outcomes and appeared to be more comfortable with a teacher-direct approach.

Second, Carell et al (1989, P.647) found that semantic mapping has proved to be good alternative to traditional pre-reading and post reading activities (ibid, p.651). Another study examined the possible effects of metacognitive strategy instruction on reading processes and reading comprehension was conducted by Cotterall (1990). The findings indicated that the learners benefited from the strategy instructi on. The next study conducted by Salataci and Akyel in 2002 who indicated that nonproficient L1 and L2 readers either don't possess knowledge about strategies or mainly engage in bottom-up strategies. The findings of these studies also indicate that strategy instruction with a focus on comprehension monitoring can help less skilled readers overcome their difficulties in reading. The types of strategy instruction used in these studies mainly consist of teacher modeling of the strategies followed by student practice in the form of group work. The last, Salataci and Akyel (2002) in their study identified four repair strategies: restatement, re-reading, demanding relationship, and problem formulation. 
From the previous studies have been mentioned, only a few research focus on effective reading strategies to increase student comprehension. Therefore research on teacher studies in teaching reading will provide an additional dimension to this study. In additional, regarding the teacher strategies, there is a need to conduct other studies covering other areas of teacher strategies in order to gain a more complete pressure teacher strategies.

This present study aims to investigate the teacher strategies in teaching reading comprehension in EFL class. This study conducted in SMPN 7 Mataram.

In line with the background above, the problem of this study is formulated as follows: What strategies do teachers use in teaching reading comprehension?

\section{THEORETICAL REVIEW}

\section{The Strategies of Teaching Reading Comprehension}

Brown (2001: 306) delivers ten strategies of reading comprehension that can be applied in the classroom.

\section{Identify the purpose of in reading}

Efficient reading consists of clearly identifying the purpose in reading something. So, we know what we are looking for and can remove potential distracting information in doing these activities.

\section{Use graphemic rules \& pattern to aid in} bottom-up decoding (beginning level).

At the beginning level of learning English one of the difficulties students encounter in learning to read is making the correspondences between spoken and written English.

\section{Use efficient silent reading techniques for relatively rapid comprehension (for intermediate to advanced level).}

Silent reading can help students increase efficiency by teaching a few silent reading rules: (1) you don't need to pronounce each word to yourself. (2) Try to visually perceive more than one word a time, preferably phrases. (3) Unless a word is absolutely crucial to global understanding, skip over it and try to infer its meaning from its context.

\section{Skim the text for main ideas.}

Skimming consists of quickly running one's eyes across a whole text for its gist. Skimming gives readers the advantage of being able to predict the purpose of the passage, the main topic, or message, and possibly some of the developing or supporting idea.

\section{Scan the text for specific information}

Scanning is quickly searching for some particular piece or pieces of information in a text. Scanning is to ask students looking for names or date, to find a definition of a key concept, or to list a certain number of supporting detail. The purpose of scanning is to extract specific information without reading through the whole text.

\section{Use semantic mapping or clustering.}

The strategy of semantic mapping, or grouping ideas into meaningful clusters, helps the reader to provide some order to the confusion.

\section{Guess when you aren't certain}

Learners can use guessing to their advantage to: 1) Guess the meaning of a word, 2) guess a grammatical relationship (e.g., a pronoun reference), 3) guess a discourse relationship, 4) infer implied meaning (between the line), 5) guess about a cultural reference, and 6) guess content messages.

\section{Analyze Vocabulary}

Some techniques in analyze a word are: look for prefixes (co-, inter-, un-, etc) that may give clues, look for suffixes (-tion, -tive, -ally, etc) that may indicate what part of speech it is, look for roots that are familiar (e.g., intervening; come from latin "ven" that means "to come in between), look for grammatical context that might signal information, and look at the semantic context (topic) for clues.

\section{Distinguish between literal and implied meaning}

It is about top-down skill. As we know, not all language can be interpreted appropriately by attending to its literal, syntactic surface structure makes special demands on readers. Implied meaning usually has to be derived from processing pragmatic information.

\section{Capitalize on discourse makers to process relationships.}

Many discourse makers in English signal relationship among ideas as expressed through phrases, clauses, and sentences. A clear comprehension of such makers can greatly enhance learners' reading efficiency.

Barnet (1988), the National Capital Language Resource Center (2007) and Wallace (1992) propose three main stages in teaching reading comprehension: pre-reading activities, while-reading activity and post reading activity. In pre-reading stage teacher introduce students to a particular text, elicited background knowledge, and activated necessary schemata. This stage helps students define selected criteria for central theme of a story or the major argument of an essay. In this stage includes 
discussing author or text type, brainstorming, reviewing familiar stories, considering illustrations and titles, skimming and scanning (for structure, main points, and future directions).

Then, in the whiles-reading activities, teacher can help students develop reading strategies, improve their control of language, and decode problematic text passages; to help students to employ strategies while reading can be difficult, because individual students controls and needs different strategies. The strategies that should be practiced by the students are like guessing word meanings by using context clues, word formation clues, or cognate practice; considering syntax and sentence structure by noting grammatical functions of unknown words, analyzing reference words, and predicting context content, reading for specific pieces of information; and learning to use the dictionary effectively.

The third, in the post-reading activities, teacher helps students check their reading comprehension and lead them to a deeper analysis of the text. In this case, Barnet explains that the important is not to summarize the reading text, but to mesh new information into what one already knows. In this, it also to help students recognize that different strategies are appropriate with different text types. For example, scanning is an appropriate strategy to use with newspaper and advertisements whereas predicting and following text cohesion are effective strategies to use with short stories.

Then, Gibbons (2002: 84) offers some useful and relevant strategies which can be used by teachers in three reading activities. First, in before reading activities, it suggested to use predicting, sequencing, reader questions, storytelling, and sharing existing knowledge. Second, in during reading activities, it is suggested to use modeled reading, skimming and scanning, rereading for detail, shared book, word masking, pause and predict, summarizing, reading aloud, and jigsaw reading. Third, in after reading activities, it is suggested to use some activities such as, questioning the text, true/false questions, jumbled sentences, etc.

Furthermore, Tierney et al (1990) also recommend fourteen practical strategies for improvement the teaching reading comprehension in the classroom for appropriate levels. The following strategies are selected based on the purpose of this present study.

\section{PReP Technique}

The PreReading Plan (PReP) provides a teacher with a mean to prepare students to read a text selection and, at the same time, analyze their responses so as to tailor subsequent instruction to student needs. There are two procedures in using this strategy; Engaging students in group discussion around key concepts and analyzing students' response.

Moreover, Mikulecky (1990: 41) delivers the three procedures of PreP Technique, they are; (1) select a key word, phrase, of picture from the text which will stimulate group discussion. Ask the students to make this association with this words, phrase, or picture. List them on the board. (2) The students tell the reasons for association they have made. This reflecting step activates a network of additional associations. (3) Ask students for additional associations which have come to mind during the discussion and write these on the board.

\section{Anticipation Guide:}

An anticipation Guide is designed to activate students' prior knowledge about a topic by having them react to series of statements related to the major concept to be accoutered in their text reading. Thus, it also provides audients a guide for their reading.

\section{Text Preview}

A text preview is a teacher-devised introductory passage used before reading selection. It is designed to build background knowledge by providing a detailed framework for comprehending a complex narrative or expository text.

\section{ReQuest Procedure}

It uses a reciprocal questioning technique in an attempt to encourage students to formulate their own quotations about material and thereby learn purposeful, thoughtful reading. The ReQuest procedure can be applied to either a reading passage or a picture, and it is suggested for use with students at all levels. There are some steps teachers should follow in using the ReQuest Procedure, they are: preparation of material, development of readiness for strategy, development of student questioning behaviors, silent reading activity, and follow-up activity.

\section{Question-Answer Relationships}

It is designed to help students answer comprehension questions by providing them a format for analyzing the task demands of questions. This strategy seems to be appropriate for middle school students. It is a strategy that the students should identify the response demands of various questions with "right there, think and search and on my own". Then they use their knowledge to generate the answer.

Raphael (1982) offers the guidelines and students response format as a way of accustoming readers to the strategy. Rafael suggests that the focus should be on the best possible response to the questions but the students' response to a question is less important than the student's assessment of the 
task demands. It means that it would be better if the reader generated the wrong answer, but correctly identify the task demands. Thus, later when students move to determining and writing in the answer, the actual answer the reader generates become important.

In this case, Rafael suggest to students to get a week of intensive training followed by maintenance activities. There are four lessons make up the first week's intensive training. 1) Introduce students to the task demands of different questions and to provide some initial practice at identifying task demands in conjunction with answering questions. 2) Provide the students with review and further guided practice as they read slightly longer passages (75 to 150 words). 3) Extending the QAR task to a passage approximately the length of a story selection. 4) Using material typically found in the classroom; a basal story or social studies, or science chapter.

\section{GIST}

The procedure of Generating Interactions between Schemata and Text (GIST) is to provide students a format for generating or summary the statements of paragraph and short passages. It progresses from a teacher directed small-group strategy to one in which students independently generate their own summary statements. In GIST procedure, there are two versions, they are:

a) Paragraph Version.

In this term, students are asked to generate summary statements of no longer than fifteen words as they read a paragraph sentence by sentence. In doing this way, teacher may ask students to do the steps; (1) selecting appropriate paragraph, (2) students read the first sentence, (3) students generate summaries, (4) reading the first two sentences, (5) generating a summary for sentence one and two, (6) continue with the procedure for remainder of the paragraph, (7) moving beyond a sentence-by-sentence approach to a paragraph approach.

b) Short Passage Version.

It parallels with the paragraph version; (1) selecting appropriate passage, (2) reading the paragraphs, (3) students generate summaries, (4) students read and summarize subsequent paragraph, (5) generating summaries for whole passages and developing independence.

\section{Explicit Teaching of Reading Comprehension}

It is a framework for direct instruction of reading comprehension. Its intent is to get students to independently apply comprehension skills learned through explicit teaching to other reading situations. The strategy is useful for students at all levels. According to Hancock (1999: 2), in explicit teaching, teacher taught students to analyze, name, and reproduce the linguistic structures and features of the more common form of the genres. He argued that students who did these activities would enhance their literacy outcomes beside to enhance their understanding about the powerful genres for themselves.

Then, for more specifics, Pearson and Leys (1984) suggest the integral part of explicit teaching: (1) introducing to the skill or strategy through examples and review. (2) Have the children volunteer additional examples and discuss them (optional). (3) Label, define, model, and explain the skill or strategy. (4) Guided practice, (5) independent practice, and (6) application.

\section{Think-Aloud}

It is a modeling procedure based upon explicit teaching intended to make students aware of the comprehension process enlisted as reading is pursued. In this strategy, Davey (1983) offers three guidelines for the use of think-aloud, they are: teacher modeling, independent student practice with checklist, and integrated use with other materials.

\section{Induced Imagery}

It is a procedure which teachers model explicitly in hopes of helping students visualize as they read. In this strategy, Gambrell et al (1987) as cited in Tierney (1990:86) offers three guidelines for helping students' developmental pictures, they are: teacher modeling, guided practice, and independent practice.

\section{Direct Reading Activity}

Directed Reading Activity is synonymous with the basal reader lesson. The purpose of DRA is to: 1) give teachers a basic format from which to provide systematic instruction on a group basis; 2) improve students' word recognition and comprehension skills, and 3) successfully guide students through a reading selection. It becomes known as a comprehensive means to provide reading instruction to children through a reading selection.

The teacher can modify some following components of DRA to fit their students' needs: (1) Readiness. It has to do with developing concept background, creating interest, introduce new vocabulary, and establish purpose. (2) Direct silent reading. It is to follow the readiness activities. In this, students are asked to read silently the selection text to seek answer to the purpose questions that teacher has set. (3) Comprehension Check and Discussion. It is to answer the silent reading that is assigned and to stress and develop comprehension ability. (4) Oral reading. It is to follow the comprehension activities by setting the new purpose of reading. (5) Follow up. It includes the experience 
that build and suggested skill development and activities that add to, or enrich, students' understanding of the concepts in the story.

\section{Vocabulary Self-Collection Strategy}

The Vocabulary Self-Collection strategy is designed to promote growth in either students' general or content area word knowledge. It is based on their experiences and encourages independent vocabulary development. Haggard (1986) claims there are five utilities of Vocabulary Self-Collection Strategy like; 1) internal motivation exert a strong influence on vocabulary acquisition and development, 2) written text is a major source for new words and terms, 3) adult develop systematic, personalized strategies for word learning, 4) words which label or define experience are learned more quickly and easily than those which do not, and 5) the art of collecting words increases sensitivity to new words and enjoyment in word learning.

Then, there are four steps of Vocabulary SelfCollection Strategy; 1) selecting the words is to ask students to go through their assigned reading to identify one word they think should be studied further. 2) Defining the words is to ask students or group of students to nominate one word or term they believe should be learned. 3) Finalizing the words lists is to narrow down the list of words by eliminating duplications, words already known, and words that students do not wish to learn. 4) Extending word knowledge is used to enable students to refine and expand the meanings of the words on the final list.

\section{Contextual Redefinition}

Contextual Redefinition is a strategy that stresses the importance of context in predicting and verifying word meanings. Context enables students to make more informed guesses about the meaning of words in prints and to monitor those predictions by checking them for syntactic/semantic appropriateness as reading progresses. Cunningham (1989) suggests five step procedures of Contextual Redefinition, they are:

a) Select Unfamiliar Words.

In this step, teachers should examine the text to be read to select word those words (1) whose meaning may be necessary to understand the important ideas of the text, and (2) whose meaning or use may present trouble to students as they read.

b) Write a sentence.

In this case, minimally, a sentence context needs to be provided so students have appropriate clues to teach word's meaning. In this way students are be able to experience the variety of ways authors may provide help in conveying meaning.

\section{c) Present the Words in isolation}

Using an overhead transparency or a chalkboard, ask students to provide definitions for each word. It is suggested that the teacher pronounce each word as it is introduced so students at least know how the word sounds. When offering guesses, students provide a rationale for them.

d) Present the words in the Context.

In this way, students are presented each word in its appropriate context, using a sentence or sentences from the text or those developed by the teacher. In this part of the strategy, students should learn that context provides much information about the meaning of words and allows for quite informed predictions.

e) Use a Dictionary for Verification

In this step, a student or students are asked to consult a dictionary to verify the guesses offered. The dictionary definition is shared with the rest of the class, and a discussion ensues concerning the quality of the predictions given when the words are presented (a) in isolated and (b) in context.

\section{Guided Reading Procedure}

Guided Reading Procedure attempts to improve attitudinal and skill aspects of reading comprehension. Beside Guided Reading Procedure can be used with children at various levels, it seems best suited for grades three and above.

According to Manzo (1975), Guided Reading Procedure is design to: 1) assist students' unaided recall of specific information read; 2) improve the students' abilities to generate their own questions as they read; 3) develop the students' understanding of the importance of self-corrections; and 4) improve the students' abilities to organize information.

Manzo also offered six basic steps to be followed for GRP: 1) prepare the student for the reading assignment. 2) Students read and recall information. 3) Return to article for additional facts and corrections. 4) Organized the remembered material. 5) Provide students with Thoughtprovoking questions. 6) Test students on their knowledge of the information.

\section{Text Structure Strategy.}

Text Structure Strategy is designed to help students recognized and use text structure in order to better understand and recall informational type texts. Students can use an understanding of the structures as an aid in comprehending texts that have similar structure. In line with this, McGee (1982) founded that readers who are acknowledgeable about text structure have an advantage in comprehension and recall over readers who aren't aware of the organization of text. 
Then, McGee and Richgels (1986) also propose the three factors for the successful teaching of text structure, they are: 1) teacher must be knowledgeable about structure. 2) The passages used for instruction are well organized and consist of a predominant structure. 3) The students must become actively involved in using the strategy while they read and afterward.

\section{METHODOLOGY}

This present study employed a qualitative case study design. A case study was chosen because this study was to observe and to explore the teachers' strategies on teaching reading comprehension and the student's responses toward their strategy used (Cohen and Manion (1994) and Gay (1996). the participants of this study is one teacher of English who teach in SMPN 7 Mataram. The non participant classroom observation was conducted in order to identify the strategies used by EFL teachers and also to identify the students' response toward their teachers' strategies in teaching reading comprehension. Video- taping was carried out to obtain a clear picture of the activity. In analyzing the data from observation, the researcher transcribed all observation notes which were taken during the teaching and learning process.

\section{FINDING AND DISCUSSION}

The type of data gained from data observation will be discussed in relation with the research question, i.e. (1) Types of strategies used by the teachers in teaching reading comprehension.

\section{The Teachers' Strategies in Teaching Reading Comprehension.}

The data about teachers' strategies in teaching reading comprehension was presented into three teaching stages; pre-reading, while-reading and postreading.

\section{Pre-Reading Stage}

In this stage, based on the observation data, there were some techniques and instructions done by the the teachers as strategies in teaching reading comprehension. The teacher has done strategies in the following activities.

a) Opening Activity and Statement of Goal

Based on the observation data, in every teaching and learning process which observed by the researcher indicated that the teachers had done opening session when they started the lesson. They did regularly greeting, asking students' condition and checking student's attendance. The following example has shown that one of the teachers started the lesson with opening activity produced by Teacher.

T2 : Good morning everyone?

Ss : Good morning...

T2 : How are you today?

Ss : I'm fine...

T2 : Who is absent today?

Ss : Nobody

Considering the data above, $\mathrm{T}$ started the lesson with greeting "good morning", asking condition "how are you?", and checking their present. He often used those questions to start the lesson along with her teachings which were observed in this study. Based on the information above, it can be inferred that when starting a teaching, the teacher has created an opening activity to focus on students' individual preparations and to see their needs. In relation to this, Usman (2010: 91) stated that the opening activity is teacher's efforts in teaching and learning to generate the precondition of students in building their mental and attention to focus on what they are going to learn. Thus, since these opening activities were aimed to prepare the students before reading, it can be considered as one aspect of teaching reading comprehension strategies in pre-reading stage. Relating to this, Hood (2005) believes that we can make comprehension easier for our students if we prepare them for what they are going to read.

b) PreP Technique

The PreReading Plan (PReP) provides a teacher with a mean to prepare students to read a text selection and, at the same time, analyze their responses so as to tailor subsequent instruction to student needs (Tierney: 1990). Based on the observation data, the teacher has created this strategy by activating and building the students background knowledge. From four teaching cycles, he created this activity, except at the last. He usually brought a picture to the class and showed to students while ask them about the activity acted out by a person. The activities can be seen in the excerpt below.

T1 : Okay...narrative text. Today, we still study about narrative text, I'll give you another title, but before we read the text I'll give you...I'll show you a picture... like this (holding and showing a picture). Semua bisa lihat?

Ss : Bisa...

T1 : Now say about this picture, what are in this picture? 
Based on the data above, teacher tried to recall the student's knowledge by showing a picture and asking questions which purposed to explore some words related to the text that they would learn. From those activities, it can be interpreted that tacher had activated their students' knowledge by asking questions of related words to the text given. This activity is also called the brainstorming activity. Relating to this, Hood et al (2005:73) argued that brainstorming might occur around the topic title or picture. In this activity, students collect their knowledge and experiences relevant to the text, generate relevant language, and build up an expectation of meaning.

c) Text Structure Strategy

According to Tierney (1990), text structure strategy is designed to help students recognized and use text structure in order to better understand and recall informational type texts. Students can use an understanding of the structures as an aid in comprehending texts that have similar structure. Based on the data gathered from observation, the teachers has generated the activities which discussed the text types and their features. This activity will elaborate in following discussion.

\section{- Discussing Text Types and their Features}

One of the strategies which provided the teachers in teaching reading comprehension is the discussion on the text types. Data from observation showed that they used this strategy in pre-reading stage. Teacher asks and discusses the types, the procedures, characteristics and the micro features of the text that the students would read. The activities can be seen from the following extract.

T3 : Okay. O...in your LKS there is a text with the title is "my cat". Termasuk text apa itu?

Ss : Descriptive...

T3 : Apa descriptive itu? Descriptive text... (Write the board). Karangan apa itu descriptive text?

From the data given in the example above, there were some activities in pre-reading stage. In this stage, teacher delivered a descriptive text with title "My pet". After giving the title, he asked the students to identify type of the text by asking the comprehensive questions to students. In line with this, Barnet (1988) explains that the pre-reading stage includes discussing author or text type, brainstorming, reviewing familiar stories, considering illustrations and titles, skimming and scanning (for structure, main points, and future directions).

\section{d) Predicting}

Palincsar and Brown (1984) and Gibbon (2002) explained that predicting involves combining the reader's prior knowledge, new knowledge from the text, and the text's structure to create hypotheses related to the direction of the text and the author's intent in writing. In this study, the teacher did predicting using picture as their strategies in teaching reading comprehension in the pre-while stage.

This finding in line with theories of Gibbon (2002) who proposes that a set of picture relating to the story will give a chance to have some appropriate sequences. Furthermore, Palincsar and Brown (1984) explained that predicting involves combining the reader's prior knowledge, new knowledge from the text, and the text's structure to create hypotheses related to the direction of the text and the author's intent in writing.

Teacher also used title of the text to predict what the topic or text was about. The activity can be seen in the excerpt below:

T2 : The title is 'Let me share my experience.'

What do you mean by the statement 'let me share my experience'?

Ss : Giving..., giving service

T2 : Giving service? Okay, memberi pelayanan atau jasa.

Based on the data shown above, teacher delivered a title of the text to students and asked them to find the meaning and the function of that phrase. These activities were used to lead his students guessing the topic of the text and the main issue that they would read in the text. Related to this term, Gibbon (2002) explained that writing the title or the first sentence is one way to ask students predicting the kind of the text and what the text will about.

\section{While-Reading Stage}

Based on data gathered, there were some strategies used by the teacher in teaching reading comprehension at while-reading stage. Generally, the the teacher has done the following activities.

a) Reread to Check Comprehension and to Improve Their Control of Language.

In this study, the teacher had asked the students to reread the text for several times to check the students' comprehension and improve their control of language. Teacher asked the students to reread the text for three times. In this, beside to practice reading aloud, he also asked them to check students' comprehension about the text. It can be proved with her leading question which 
delivered after the last student finished reading the text. She asked "Do you understand what the text is?" and followed by using Indonesian "Paham tidak mengenai apa teks ini?"

From this data finding, it also can be inferred that teacher generated the monitor comprehension strategy. he assisted her students to do self monitoring by reading the text for several time. In relation to this, an online publication: The National Capital Language Resource Center (2007) classifies reading aloud to check comprehension as the way to monitor the comprehension before or after reading activity. Furthermore, Anderson (1999: 47) defines monitoring comprehension as a technique that is used to get readers to monitor their comprehension while reading by periodically stopping and asking themselves. Thus, Anderson suggested that this technique or strategy can be applied for teaching reading comprehension skill in several possible classrooms.

b) Direct Reading Activity

In this strategy, the students are asked to read the text silently and the teacher should prepare one or two comprehension-level questions for their reading. The excerpt below shows the activity of silent reading in the classroom.

T2 : Okey now, I give you time five minutes to read this text, please.... Silahkan dibaca dulu waktunya lima menit.

Ss : (they read the text silently)

T2 : (After five minutes) Ok finish? Terus, apa yang bisa kamu ambil dari jalan cerita itu? Apa pokok pikiran utamanya?

Regarding the observation data above, teacher asked the students to read the selected text silently. He gave a limited time for silent reading. When the students had finished reading the text silently for five minutes, he asked them comprehension question about the text. Related to this case, Crawford (2005: 42) stated that DRA is a strategy for directing the students' silent reading with comprehension-level questions. This method is a designed to support students' reading comprehension by guiding them to key points in the text and providing opportunities to discuss its meaning with their classmates.

c) Vocabulary Self-Collection \& Contextual Redefinition Strategies

One of the activities that students did in this stage was to identify the new or difficult words from the text. This activity often created before reading aloud. The instruction in the excerpt below:

Volume 6, No. 3, Mei 2012
T2 : Okay, sekarang kamu cari the difficult words. Ini akan mempermudah kamu dalam menterjemahkan nantinya. Okay. Apa kata-kata yang sulitnya yang kamu jumpai didalam teks ini?

Ss : dinner...

From the data above, teacher asked students whether they have problems or difficulties in reading some new vocabularies in the text after reading aloud. Relevance to this, Tierney (1990) vocabulary self-collection strategy is designed to promote growth in either student's general or content area word knowledge. It is based on their experiences and encourages independent vocabulary development.

\section{Post-Reading Stage}

In this study, the teacher provided this strategies in the activities such as: 1) questioning, clarifying and justifying comprehension. 2) Reviewing and follow-up strategy.

a) Questioning, Clarifying and Justifying Comprehension.

- Questioning to evaluate comprehension in a particular tasks or area

Palincsar and Brown (1984) stated that questioning involves the identification of information, themes, and ideas that are central and important enough to warrant further consideration. Questioning provides a context for exploring the text more deeply and assuring the construction of meaning. The example below is one of the teachers and students' activities in creating the task in the classroom.

T3 : (After reading the text) Nah, kerja kelompoknya sekarang menentukan apa judul dari teks ini. Sudah baca tadi kan?

Ss : Sudah...

T3 : Yang kedua, you answer the questions from number one until number five. Berdasarkan text diatas. Yang ketiga, kamu membuat pernyataan, pada activity itu.

In the example above, after reading activities teacher gave the instructions to his students to do some tasks which accompanied the text. He asked them to state the title of the text. Then he asked them to answer the questions given based on the information from the text, and next he also asked them to state the statement given true or not. In relation to this, an online publication: The National Capital Language Resource Center (2007) delivered three kinds activities to evaluate comprehension in the post-reading stage; evaluate comprehension in a particular task or area, evaluates overall progress in reading and in 
particular types of reading tasks and decide if the strategies used were appropriate for the purpose and the task modifies strategies if necessary.

\section{- Clarifying and Justifying the Students'} Answers.

One of the teachers had done this activity as her strategy in post-reading stage. The observation data below is presented as the example. This data was gathered in the classroom interaction below.

$\mathrm{T} 1$ : (After five minutes for additional time) have you finished now?

Ss : Yes... (Answer some students and some students are still doing the task).

T1 : Okay number 2 Faturrahman, Who was the main character?

S24 : Andrew...

T1 : Do you agree with Faturrahman's answer?

Ss : Yes...

In the example above, teacher created the task for his students which taken from the task accompanied the passage. In doing this, he asked them to answer the questions based on the text. It means that the students should read the text again before they answer the questions.

In relevance to this, Anderson, (1999:47) identified that Justify comprehension as the possible application for teaching reading comprehension. He mentioned that justify comprehension is a technique that used to ask students to read a passage: then ask comprehension questions or use the questions that often accompany passages in commercial texts, and then ask the class to justify their answer to the comprehension questions. Then,

\section{- Asking Questions for Specific Information / Scanning}

In this study, from the data of observation, it can be seen that the teacher seemed to use scanning in almost of the questions of tasks. It might be because of the text that each teacher use was almost the same from one teaching practice to others. It is relevant with the theories of Hood (2005) formulates the aims of scanning activities in order to show students how to find information quickly and to show them that we don't need to read every word of a text to get the information we want, and how we read a text is determined by our purpose for reading.

\section{Reviewing and Follow-up Strategies \\ 1. Reviewing}

Considering the data from observation, all the teachers in the study had done the reviewing as their strategy in teaching reading especially in post- reading stage. the extract below is the example which taken from observation data.

T1 : That's right, Okay. I think time isn't enough for us. Karena waktu kita mau habis..., e... saya rasa sampai disini dahulu pelajaran kita hari ini. Sebagai kesimpulan pada hari ini, kita sudah mempelajari narrative text. Masih ingatkan karakteristik narrative teks itu?

T1 : Ada orientatation...

Ss : Orientation, complication, resolution, reorientation...

In the example above, teacher had done reviewing strategy for teaching reading comprehension. He asked about the characteristic of narrative text. She reviewed the generic structure of narrative text. In relation to this, Brown (2001) proposes one of techniques for series of approaching in a reading text is reviewing. He suggested the review is to assess the importance of what one has just read and long-term of association. Then Nuttal (1996: 129) defines Review as to think about what you have learn, and organize the information in your mind. Consider its implications for other things you know.

\section{Assignment and Following-up}

The teachers in this present study had created the follow-up activity in form of homework. In line with this discussion, Wallace (1992: 101) stated that other texts lend themselves to follow-up activities such as role play. Furthermore, according to Phillips (1985) as cited in Barnet (1988) told that Follow-up exercises take students beyond the particular reading text in one of two ways: by transferring reading skills to other texts or by integrating reading skills with other language skills. In addition, Barnet (1988) also stated that follow-up is the effective strategies to use with short stories.

\section{CONCLUSION}

Regarding to the research problem, it is can be concluded that all of the teachers have implemented several strategies in teaching reading to encourage the students in comprehend the text. In the prereading stage, there were some activities they conduct; they are opening activity and instructional goal, activate and build students background knowledge, discuss on text types and their features, and considering illustration and title. Then, in the while-reading stage, they conducted reread to check comprehension and to improve their control of language, silent reading and asking the main point of reading, identifying and clarification unfamiliar vocabulary and passage structure, and retelling the text. In the post-reading stage, they created evaluate 
comprehension in a particular tasks or area, ask the student to read the passage, then ask comprehension questions, after that ask class to justify their answers, ask questions for specific information / scanning, reviewing and assessing the lesson, and assignment and following-up.

\section{REFERENCES}

Anderson (1999). Exploring Second Language Reading: Issues and Strategies. Boston, MA: Heinle \& Heinle.

Barnet, M.A. (1988). Teaching Reading in a Foreign Language. [online] retrieved at: http://www.erictdigests.org/pre9211/reading.htm. [October, 20 2009]

Brown, H.D. (2001) Teaching by Principles: An Interactive Approach to Language Pedagogy. Second Edition. New York: Pearson Education Company.

Carrel, Patrical L., Pharis, B.G., \& Liberto, J. C. 91989). Metacognitive strategy training for EFL reading. TESTOL Querterly, 23(4), 674-678.

Cohen, L., \& Manion, L. (1994). Research Methods in Education. ( $4^{\text {th }}$ Edition). New York: Routledge.

Cuningham, J.W., P.M. Cuningham, and S.V. Arthur. (1981) Middle and Secondary School Reading. In Tierney, R.J., Readence, J.E., \& Dishner, E.K. (1995). Reading Strategies and Practices. Boston: Allyn and Bacon.

Davey, B. (I993). Think-aloud - Modelling the cognitive processes of reading comprehension. In Tierney, R.J., Readence, J.E., \& Dishner, E.K. (1995). Reading Strategies and Practices. Boston: Allyn and Bacon.

DEPDIKNAS. (2006). Panduan Penyusunan Kurikulum Tingkat Satuan Pendidikan Jenjang Pendidikan Dasar dan Menengah. Jakarta: BSNP.

Fraenkel, J.R., \& Wallen, N.E. (2007). How to Design and Evaluate Research in Education. ( Sixth Edition). New York: McGraw Hill.

Gay, L.R. (1992). Educational Research: Competencies for Analysis and Application. $\left(4^{\text {th }}\right.$ Edition) New York: Macmillan Publishing Company.

Gibbons, P. (2002). Scaffolding Language Scaffolding Learning: Teaching Second
Language Learners in the Mainstream Classroom. USA, Portsmouth: Heinemann.

Haggard, M,R. (1986b). The Vocabulary selfselection strategy: Using students interest and word knowledge to enhance vocabulary growth. In Tierney, R.J., Readence, J.E., \& Dishner, E.K. (1995). Reading Strategies and Practices. Boston: Allyn and Bacon.

Hancock, J. (1999), The Explicit of Teaching Reading. Adeleide, South Australia: The International Reading Association.

Hillerich, R.L. (1983) The Principle's Guide to Improving Reading Instruction. Massachusetts: Allyn and Bacon. Inc.

Hood, S., Solomon, N., \& Burns, A. (1996). Focus on Reading (New Edition). Sydney: Macquarie University.

Li, H., \& Wilhelm, K.H. (2008) Exploring Pedagogical Reasoning: Reading Strategy Instruction from Two Teachers Persfectives. The Reading Matrix Vol. 8, No.1. Retrieved at: hualigz@126.com, kimhw@umac.mo

Manzo (1975). Guided Reading Procedure. In Tierney, R.J., Readence, J.E., \& Dishner, E.K. (1995). Reading Strategies and Practices. Boston: Allyn and Bacon.

McGee, L.M. (1982). Awareness of Text Structure: Effects on children's recall of expository text. In Tierney, R.J., Readence, J.E., \& Dishner, E.K. (1995). Reading Strategies and Practices. Boston: Allyn and Bacon.

McGee, L.M., \& D.J. Richgels. (1986) Attending to text structure: A Comprehension Strategy. In Tierney, R.J., Readence, J.E., \& Dishner, E.K. (1995). Reading Strategies and Practices. Boston: Allyn and Bacon.

Mikulecky, B.S. (1990). A Short Course in Teaching Reading Skills. New York: Addison-Wesley Publishing Company. Inc.

Nunan, D. (1999). Second Language Teaching \& Learning. Boston, Massachusetts: Heinle \& Heinle.

Nuttal, C. (1996). Teaching Reading Skills in a Foreign Language. Cambridge: Cambridge University Press.

Palincsar, A., \& Brown, A. (1984). Reciprocal Teaching of Comprehension-fostering and Comprehension-fostering Activities. In Doolittle, P.E. et al (2006). Reciprocal Teaching for Reading Comprehension in Higher Education: A Strategy for Fostering 
the Deeper Understanding of Texts. Salataci and Akyel (2002). Electronik jurnal of International Journal of Teaching and Learning in Higher Education. Number 2, 106-11. http://www.isetl.org/ijtlhe/

Pearson, P.D., \& M. Leys. (1984). Teaching Comprehension. In T.L. Harris \& E.J. Cooper (Eds). Reading, thinking and concept development: Strategies for the classroom. In Tierney, R.J., Readence, J.E., \& Dishner, E.K. (1995). Reading Strategies and Practices. Boston: Allyn and Bacon.

Raphael, T.E. (1982). Improving Questionanswering performance through instructional. In Tierney, R.J., Readence, J.E., \& Dishner, E.K. (1995). Reading Strategies and Practices. Boston: Allyn and foreign language teaching. Vol.1

The National Capital Language Resource Center (2007). Goals and Techniques for Teaching Reading [online]. Retrieved at: http://www.nclrc.org/essentials/reading/goal sread.htm. [ August 10th, 2008]

Tierney, R.J., Readence, J.E., \& Dishner, E.K. (1995). Reading Strategies and Practices. Boston: Allyn and Bacon.

Usman, U. (1990). Menjadi Guru Profesional. Bandung: Rosda Karya.

Wallace, C. (1992). Reading. Cambridge: Oxford University Press.

Bacon. 